\title{
KEMAMPUAN BERFIKIR FORMAL SISWA SMA DITINJAU DARI GAYA KOGNITIF FIELD DEPENDENT DAN FIELD INDEPENDENT
}

\author{
Nurhardiani $^{1} \&$ M. Syawahid ${ }^{2}$ \\ 12Universitas Islam Negeri (UIN) Mataram \\ ${ }^{1}$ nurhardiani25@gmail.com, ${ }^{2}$ syawahid@uinmataram.ac.id
}

\begin{abstract}
Abstrak
Tujuan penelitian ini untuk mendeskrifsikan gaya kognitif field independent dan field dependent siswa SMA ditinjau dari jenis kelamin siswa. Siswa diminta untuk mengerjakan tes GEFT dan soal kemampuan matematika kemudian diwawancarai. Indikator yang digunakan untuk mengukur kemampuan berpikir formal adalah: (1) mampu memberikan alasan disetiap langkah yang dilakukan hingga memperoleh kesimpulan dengan benar, (2) mampu memberikan alasan disetiap langkah yang dilakukan hingga memperoleh kesimpulan kurang tepat atau terdapat kesalahan, (3) tidak dapat memberikan alasan disetiap langkah yang dilakukan. Dari hasil penelitian, diperoleh dari 66 siswa yang diberikan tes GEFT, terdapat 30 siswa dengan gaya kognitif field independent dan 36 siswa dengan gaya kognitif field dependent. Dari 30 siswa dengan gaya kognitif field independent diperoleh 2 siswa dengan kemampuan berpikir formal sangat baik berarti hanya 7\%, 19 siswa dengan kemampuan berpikir formal baik berarti 63\%, dan 9 siswa dengan kemampuan berpikir formal cukup baik berarti 30\%. Sedangkan yang dari 36 siswa dengan gaya kognitif field dependent diperoleh 6 siswa dengan kemampuan berpikir formal cukup baik artinya $16 \%$ dan 30 siswa dengan kemampuan berpikir formal kurang artinya $84 \%$. Kemampuan berpikir formal sangat baik ditunjukkan dengan kemampuan memberikan alasan disetiap langkah yang dilakukan hingga memperoleh kesimpulan yang benar pada dua soal yang diberikan. Kemampuan berpikir formal baik ditunjukkan dengan kemampuan memberikan alasan disetiap langkah yang dilakukan hingga memperoleh kesimpulan kurang tepat atau terdapat kesalahan pada salah satu soal yang diberikan. Kemampuan berpikir formal cukup baik ditunjukkan dengan kemampuan memberikan alasan disetiap langkah yang dilakukan hingga memperoleh kesimpulan kurang tepat atau terdapat kesalahan pada dua soal yang diberikan. Kemampuan berpikir formal kurang baik. ditunjukkan dengan ketidakmampuan siswa dalam memberikan alasan disetiap langkah yang diberikan.
\end{abstract}

Kata Kunci : Berpikir Formal, Menyelesaikan Masalah, Gaya Kognitif

\section{PENDAHULUAN}

Tujuan diberikan mata pelajaran matematika dalam peraturan menteri pendidikan nasional Nomor 2 tahun 2006 tentang standar isi adalah agar membekali siswa dengan kemampuan berfikir logis, analitis, sistematis, kritis dan kreatif serta kemampuan bekerja sama. dari hal 
tersebut, kemampuan berfikir logis merupakan salah satu kemampuan yang harus diberikan kepada siswa.

Kemampuan berfikir logis menurut menurut siswono (2008:13) berfikir logis dapat diartikan sebagai kemampuan siswa untuk menarik kesimpulan yang sah menurut aturan logika dan dapat membuktikan kesimpulan itu benar (valid) sesuai dengan pengetahuan-pengetahuan sebelumnya yang sudah diketahui. Dari hal tersebut, kemampuan berfikir logis merujuk pada kemampuan membuktikan suatu pertanyaan sesuai dengan logika matematika dengan mampu memberikan kesimpulan disetiap langkah yang dilakukan.

Dalam matematika suatu kalimat yang bernilai benar saja atau salah saja disebut sebagai pernyataan. Suatu pernyataan memerlukan bukti nilai kebenarannya dengan menggunakan aksioma, definisi, lema, teorema dan lain sebagainya. Proses pembuktian tersebut dilakukan dalam bentuk formal matematis. Menurut Tall (2008e) dunia matematika terbagi dalam tiga bagian yaitu dunia perwujudan konseptual, dunia simbiol perceptual dan dunia formal-aksiomatik. Dalam dunia formal aksimatik, konstruksi makna dari definisi yang didasarkan pada objek dikenal menuju konsep formal berdasarkan pada set-teoritik definisi.

Pembelajaran matematika secara kognitif, tentunya tidak lepas dari suatu aktivitas berpikir yaitu berpikir matematis. Berpikir matematis adalah aktivitas mental yang terjadi ketika seseorang memproses pengetahuan matematika untuk menyelesaikan masalah matematika. Ferri (2012) mengungkapkan: "A mathematical thinking style is the way in which an individual prefers to present, to understand and to think through mathematical facts and connections by certain internal imaginations and/or externalized representations". Ungkapan Ferri tersebut dapat diartikan bahwa sebuah gaya berpikir matematis adalah cara seseorang memilih untuk merepresentasikan, memahami, dan memikirkan tentang fakta matematika dan hubungannya dengan imajinasi internal tertentu dan/ atau representasi eksternal. 
Teori perkembangan kognitif piaget adalah salah satu teori yang menjelaskan bagaimana anak beradaptasi dengan dan menginterpretasikan objek dan kejadian-kejadian disekitarnya. Bagaimana anak mempelajari ciriciri dan fungsi dari objek-objek, seperti mainan, perabot, dan makanan, serta objek-objek sosial seperti diri, orang tua, dan teman. Menurut Jean Piaget, perkembangan manusia melalui empat tahap perkembangan kognitif dari lahir sampai dewasa. Setiap tahap ditandai dengan munculnya kemampuan intelektual baru di mana manusia mulai mengerti dunia yang bertambah kompleks.

Tabel 1.1. Tahap Perkembangan Kognitf Jean Piaget

\begin{tabular}{|l|l|l|}
\hline Tahap-Tahap & Umur & Kemampuan \\
\hline Sensori-motorik & $0-2$ tahun & $\begin{array}{l}\text { Menunjuk pada konsep permanensi } \\
\text { objek yaitu kecakapan psikis untuk } \\
\text { mengerti bahwa suatu objek masih } \\
\text { tetap ada. Meskipun pada waktu itu } \\
\text { tidak tampak oleh kita dan tidak } \\
\text { bersangkutan dengan aktivitas pada } \\
\text { waktu itu. Tetapi, pada tahap ini } \\
\text { permanen objek belum sempurna. }\end{array}$ \\
\hline Pra-operasional & $2-7$ tahun & $\begin{array}{l}\text { Perkembangan semampuan } \\
\text { menggunakan simbol-simbol yang } \\
\text { menggambarkan objek yang ada } \\
\text { disekitarnya. Berpikir masih egosentris } \\
\text { dan berpusat. }\end{array}$ \\
\hline Operasional & $7-11$ tahun & $\begin{array}{l}\text { Mampu berpikir logis. Mampu konkrit } \\
\text { memperhatikan lebih dari satu dimensi } \\
\text { sekaligus dan juga dapat } \\
\text { menghubungkan dimensi ini satu sama } \\
\text { lain. Kurang egosentris. Belum bisa } \\
\text { berpikir abstrak. }\end{array}$ \\
\hline Operasional Formal & $\begin{array}{l}\text { 11 tahun } \\
\text { Dewasa }\end{array}$ & $\begin{array}{l}\text { Mampu berpikir abstrak dan dapat } \\
\text { menganalisis masalah secara ilmiah } \\
\text { dan kemudian menyelesaikan masalah. }\end{array}$ \\
\hline
\end{tabular}

Dalam teori perkembangan kognitif Piaget, masa remaja adalah tahap transisi dari penggunaan berpikir konkret secara operasional ke berpikir formal secara operasional. Remaja mulai menyadari batasan-batasan pikiran mereka. Mereka berusaha dengan konsep-konsep yang jauh dari pengalaman mereka sendiri. Inhelder dan Piaget (1972) mengakui bahwa perubahan otak pada pubertas mungkin diperlukan untuk kemajuan kognitif remaja. Dapat 
disimpulkan bagi siswa SMA sudah memasuki tahap perkembangan operasional formal.

Dalam pembelajaran matematika, pemecahan masalah merupakan aktivitas yang penting. Holmes (dalam NCTM, 1998) menyatakan bahwa pemecahan masalah adalah "jantung" dari matematika (heart of mathematics). Istilah jantung matematika menunjukkan bahwa keberadaan pemecahan masalah dalam matematika sangat diperlukan dan harus ada dalam setiap permasalahan matematika. Demikian juga Suryadi (dalam Suherman, dkk, 2001) menyebutkan bahwa pemecahan masalah matematika merupakan salah satu kegiatan matematika yang dianggap penting baik bagi guru maupun siswa di semua tingkat, mulai dari SD sampai SMA bahkan perguruan tinggi.

Unsur penting dalam pemecahan masalah yang bersifat pembuktian adalah kemampuan berpikir formal. Masalah pembuktian merupakan tingkat masalah yang paling tinggi dalam masalah matematika karena tidak hanya membutuhkan pemahaman konsep saja dalam penyelesaiannya, kemampuan berpikir logis menjadi unsur utama dalam menyelesaikannya.

Kemampuan berpikir formal bisa ditinjau dari gaya kognitif seseorang. Aiken (1997:156) mendefinisikan gaya kognitif sebagai pendekatan untuk menerima, mengingat dan berpikir yang cenderung digunakan individu untuk memahami lingkungannya. Dengan kata lain gaya kognitif sebagai salah satu dari dimensi perbedaan individu, melihat dari karakteristik siswa dalam menanggapi, memproses, menyimpan, berpikir, dan menggunakan informasi untuk menanggapi suatu tugas atau menanggapi berbagai jenis situasi lingkungan. Gaya kognitif berbeda dengan inteligensi dan dimensi kemampuan yang lain. Witkin dan Arsch (1979:8) membagi gaya kognitif atas dua yaitu field independent dan field dependent. Witkin membedakan individu yang memiliki gaya kognitif field independent dan field dependent melalui kemampuan menjawab tes Group Embeded Figure Test (GEFT) dalam waktu yang ditentukan serta kriteria tertentu. Perangkat GEFT merupakan bentuk pemecahan masalah matematika geometri 
untuk mencari atau menemukan bagian-bagian bangun geometri sederhana yang terpisah dari bagian yang kompleks. Individu dengan field independent berbeda dengan individu dengan field dependent dalam banyak karakteristik antara lain dalam pemprosesan informasi, daya belajar, dan cara berpikir.

Perbedaan itu antara lain adalah individu dengan field independent cenderung reflektif dalam berpikir, lebih kreatif, kreativitas berkembang berdasarkan rasional, cenderung pada materi pelajaran yang abstrak, impersonal, fakta, analitis, berdaya otak kiri, cenderung berpikir divergen, dan kurang dapat bersosialisasi dengan baik, lebih bersifat individualistis. Sedangkan individu dengan field dependent cenderung impulsif dalam berpikir, kurang kreatif, kreativitas berkembang berdasarkan imaginasi (berpikir lateral), cenderung pada materi pelajaran yang bersifat kemanusiaan, konten sosial, dan fantasi, berdaya otak kanan, cenderung kurang berpikir divergen, dan dapat menjalin hubungan sosial dengan baik (Town, 2010).

Berdasarkan karakteristik dari dua gaya kognitif field independent dan field dependent tidak dapat disimpulkan bahwa siswa dengan gaya kognitif yang satu lebih unggul atau lebih rendah dari siswa dengan gaya kognitif yang lain. Karena dari karakteristik kedua gaya kognitif ini masingmasing mempunyai kelebihan dan kekurangan. Berdasarkan karakteristik masing-masing gaya kognitif jika dihubungkan dengan berpikir formal bisa dikemukakan adanya kaitan antara gaya kognitif dengan berpikir formal.

Berpikir formal berhubungan dengan gaya kognitif. Hal ini dikarenakan perbedaan gaya kognitif dapat menghasilkan perbedaan dalam berpikir formal. Untuk melihat kebenaran ini, peneliti melakukan uji coba sederhana yakni dengan memberikan soal matematika yang dapat memacu berpikir formal siswa SMA. Berdasarkan hasil uji coba, diketahui bahwa siswa laki-laki memiliki gaya kognitif field independent langsung membuat pola, memanipulasi bilangan untuk mendapatkan jawaban. Sedangkan siswa perempuan yang memiliki gaya kognitif field dependent mampu menyajikan soal dalam bentuk gambar dan memanipulasi 
variabel sehingga dapat menyelesaikan masalah yang diberikan. Sehingga terdapat perbedaan berpikir formal diantara siswa yang memiliki gaya kognitif dan gender berbeda. Berdasarkan uraian di atas maka peneliti tertarik untuk melakukan penelitian yang mengidentifikasikan profil berpikir formal siswa SMA dalam menyelesaikan masalah matematika ditinjau dari gaya kognitif.

Dalam penelitian ini, kemampuan berpikir formal yang dimaksud adalah kemampuan siswa dalam menyelesaian masalah matematika dengan memberikan alasan yang logis disetiap langkah yang dilakukan hingga memperoleh kesimpulan yang benar. jika dikaitkan dengan teori perkembangan Piaget, kemampuan ini berada pada kategori berpikir formal F3. Indikator yang dapat digunakan untuk mengukur kemampuan berpikir formal dalam penelitian ini adalah:

1. Mampu memberikan alasan disetiap langkah yang dilakukan hingga memperoleh kesimpulan dengan benar

2. Mampu memberikan alasan disetiap langkah yang dilakukan hingga memperoleh kesimpulan kurang tepat atau terdapat kesalahan.

Tidak dapat memberikan alasan disetiap langkah yang dilakukan.

\section{METODE PENELITIAN}

Penelitian ini dilaksanakan di SMAN 2 Mataram. Subjek dalam penelitian ini adalah siswa kelas X di SMAN 2. Pemilihan subjek berdasarkan gaya kognitif dilakukan dengan mengadakan tes GEFT (Group Embeded Figures Test) terjemahan yang dikembangkan oleh Witkin, et al (1971). Secara lebih terperinci penentuan subjek FI dan FD adalah sebagai berikut. Siswa kelas X di SMAN 2 Mataram diminta untuk mengerjakan tes GEFT dan soal kemampuan matematika. Berdasarkan skor yang diperoleh siswa didapatkan dua kelompok siswa yaitu siswa dengan gaya kognitif FI dan FD. Dari kedua kelompok gaya kognitif diberikan soal kemampuan matematika dan melakukan wawancara. Dalam penelitian ini untuk mengumpulkan data digunakan instrumen utama yaitu peneliti sendiri, karena peneliti sebagai pengumpul data dan menginterpretasi data yang 
diperoleh selama proses penelitian. Selain instrumen utama tersebut digunakan instrumen pendukung, yaitu: 1) Tes GEFT, 2) Soal Kemampuan Berpikir Formal, dan 3) Pedoman Wawancara.

\section{HASIL PENELITIAN DAN PEMBAHASAN}

Dalam penelitian ini, telah dilakukan identifikasi kemampuan berpikir fomal ditinjau dari gaya kognitif siswa. Penelitian ini berusaha mendeskripsikan tingkat kemampuan berpikir formal yang dimiliki oleh siswa dengan gaya kognitif independent dan siswa dengan gaya kognitif field dependent. Berikut dibahas hasil penelitian dalam penelitian ini.

\section{A. Kemampuan Berpikir Formal Siswa dengan Gaya kognitif field independent}

Dari hasil penelitian, diperoleh bahwa dari 66 siswa yang diberikan tes GEFT, terdapat 30 siswa dengan gaya kognitif field independent. Dari 30 siswa dengan gaya kognitif field independent tersebut diperoleh siswa 2 siswa dengan kemampuan berpikir formal sangat baik berarti hanya $7 \%$ siswa yang berkemampuan berpikir formal sangat baik, 19 siswa dengan kemampuan berpikir formal baik berarti 63\% siswa yang berkemampuan berpikir formal baik, dan 9 siswa dengan kemampuan berpikir formal cukup baik berarti 30\% siswa yang berkemampuan berpikir formal cukup. Data ini diperoleh setelah siswa diberikan tes kemampuan berpikir formal. Berikut pembahasan lebih lanjut dari kemampuan berpikir formal siswa dengan gaya kognitif field independent.

Berikut data diatas disajikan dalam bentul tabel dibawah ini.

Tabel 3.1 Kemampuan Berpikir Formal Siswa Berdasarkan Gaya Kognitif FI

\begin{tabular}{|r|l|r|l|r|l|}
\hline No & \multicolumn{1}{|c|}{ Nama } & $\begin{array}{c}\text { Sko } \\
\text { r }\end{array}$ & Gaya Kognitif & Skor & Ket \\
\hline 1 & Dian Fakhira & 11 & $\begin{array}{l}\text { Field } \\
\text { Independent }\end{array}$ & 75 & Baik \\
\hline 2 & Wulandari Salsabila & 16 & $\begin{array}{l}\text { Field } \\
\text { Independent }\end{array}$ & 75 & Baik \\
\hline 3 & Baiq Elliana Hidayati Khoiri & 11 & $\begin{array}{l}\text { Field } \\
\text { Independent }\end{array}$ & 50 & Cukup Baik \\
\hline 4 & Alifa Tasya Azzahra & 10 & $\begin{array}{l}\text { Field } \\
\text { Independent }\end{array}$ & 50 & Cukup Baik \\
\hline
\end{tabular}


Nurhardiani \& Syawahid, M. (2017). KEMAMPUAN BERFIKIR FORMAL SISWA SMA DITINJAU DARI GAYA KOGNITIF FIELD DEPENDENT DAN FIELD INDEPENDENT. JURNAL TATSQIF, 15(2), Retrieved from:

\begin{tabular}{|c|c|c|c|c|c|}
\hline 5 & Yulia Azmi Khotimah & 10 & $\begin{array}{l}\text { Field } \\
\text { Independent }\end{array}$ & 75 & Baik \\
\hline 6 & $\begin{array}{l}\text { Sasa Bella Cintia Rizki } \\
\text { Perdana }\end{array}$ & 16 & $\begin{array}{l}\text { Field } \\
\text { Independent }\end{array}$ & 100 & Sangat Baik \\
\hline 7 & Imam Darmawan & 16 & $\begin{array}{l}\text { Field } \\
\text { Independent }\end{array}$ & 75 & Baik \\
\hline 8 & $\begin{array}{l}\text { Lalu Muhaman Arfian Arya } \\
\text { G. }\end{array}$ & 18 & $\begin{array}{l}\text { Field } \\
\text { Independent }\end{array}$ & 100 & Sangat Baik \\
\hline 9 & Wiliam Arishandi & 16 & $\begin{array}{l}\text { Field } \\
\text { Independent }\end{array}$ & 75 & Baik \\
\hline 10 & Roberto Fedricho & 11 & $\begin{array}{l}\text { Field } \\
\text { Independent }\end{array}$ & 50 & Cukup Baik \\
\hline 11 & Lalu M. Riza Rizky & 11 & $\begin{array}{l}\text { Field } \\
\text { Independent }\end{array}$ & 75 & Baik \\
\hline 12 & Azky Saputra & 12 & $\begin{array}{l}\text { Field } \\
\text { Independent }\end{array}$ & 75 & Baik \\
\hline 13 & Ibnu Athailah & 15 & $\begin{array}{l}\text { Field } \\
\text { Independent }\end{array}$ & 75 & Baik \\
\hline 14 & Sharon Jodie Atmodjo & 14 & $\begin{array}{l}\text { Field } \\
\text { Independent }\end{array}$ & 75 & Baik \\
\hline 15 & Allya Kurnia Madani & 11 & $\begin{array}{l}\text { Field } \\
\text { Independent }\end{array}$ & 75 & Baik \\
\hline 16 & Desi Ayu Kurniasari & 10 & $\begin{array}{l}\text { Field } \\
\text { Independent }\end{array}$ & 75 & Baik \\
\hline 17 & Kirna Isma Amelia & 12 & $\begin{array}{l}\text { Field } \\
\text { Independent }\end{array}$ & 50 & Cukup baik \\
\hline 18 & Suleni & 10 & $\begin{array}{l}\text { Field } \\
\text { Independent }\end{array}$ & 75 & Baik \\
\hline 19 & Diah Melati Anjansari & 10 & $\begin{array}{l}\text { Field } \\
\text { Independent }\end{array}$ & 50 & Cukup baik \\
\hline 20 & Anggelina Ayu Savitri & 15 & $\begin{array}{l}\text { Field } \\
\text { Independent }\end{array}$ & 75 & Baik \\
\hline 21 & Evelyn Ayu Talitha & 13 & $\begin{array}{l}\text { Field } \\
\text { Independent }\end{array}$ & 75 & Baik \\
\hline 22 & Putri Agustina & 12 & $\begin{array}{l}\text { Field } \\
\text { Independent }\end{array}$ & 75 & Baik \\
\hline 23 & Nyoman Anggri Wedhani & 10 & $\begin{array}{l}\text { Field } \\
\text { Independent }\end{array}$ & 50 & Cukup baik \\
\hline 24 & $\begin{array}{l}\text { I Gde Sadru Dharmika } \\
\text { Utrayana }\end{array}$ & 12 & $\begin{array}{l}\text { Field } \\
\text { Independent }\end{array}$ & 50 & Cukup baik \\
\hline 25 & Lalu Rafly Pratama A.P & 18 & $\begin{array}{l}\text { Field } \\
\text { Independent }\end{array}$ & 75 & Baik \\
\hline 26 & Novan Adhi Nugroho & 18 & $\begin{array}{l}\text { Field } \\
\text { Independent }\end{array}$ & 75 & Baik \\
\hline 27 & Diro Satrio Wibowo T & 16 & $\begin{array}{l}\text { Field } \\
\text { Independent }\end{array}$ & 75 & Baik \\
\hline 28 & Gede Sudani Aditya & 12 & $\begin{array}{l}\text { Field } \\
\text { Independent }\end{array}$ & 50 & Cukup baik \\
\hline 29 & I Kadek Dwi Jendra P & 14 & $\begin{array}{l}\text { Field } \\
\text { Independent }\end{array}$ & 50 & Cukup baik \\
\hline 30 & Ary Rahim Maulana & 15 & $\begin{array}{l}\text { Field } \\
\text { Independent }\end{array}$ & 75 & Baik \\
\hline
\end{tabular}


Deskripsi hasil jawaban siswa dengan kemampuan sangat baik, baik, cukup baik dan kurang baik sebagai berikut.

1. Siswa dengan Kemampuan Berpikir Formal Sangat Baik

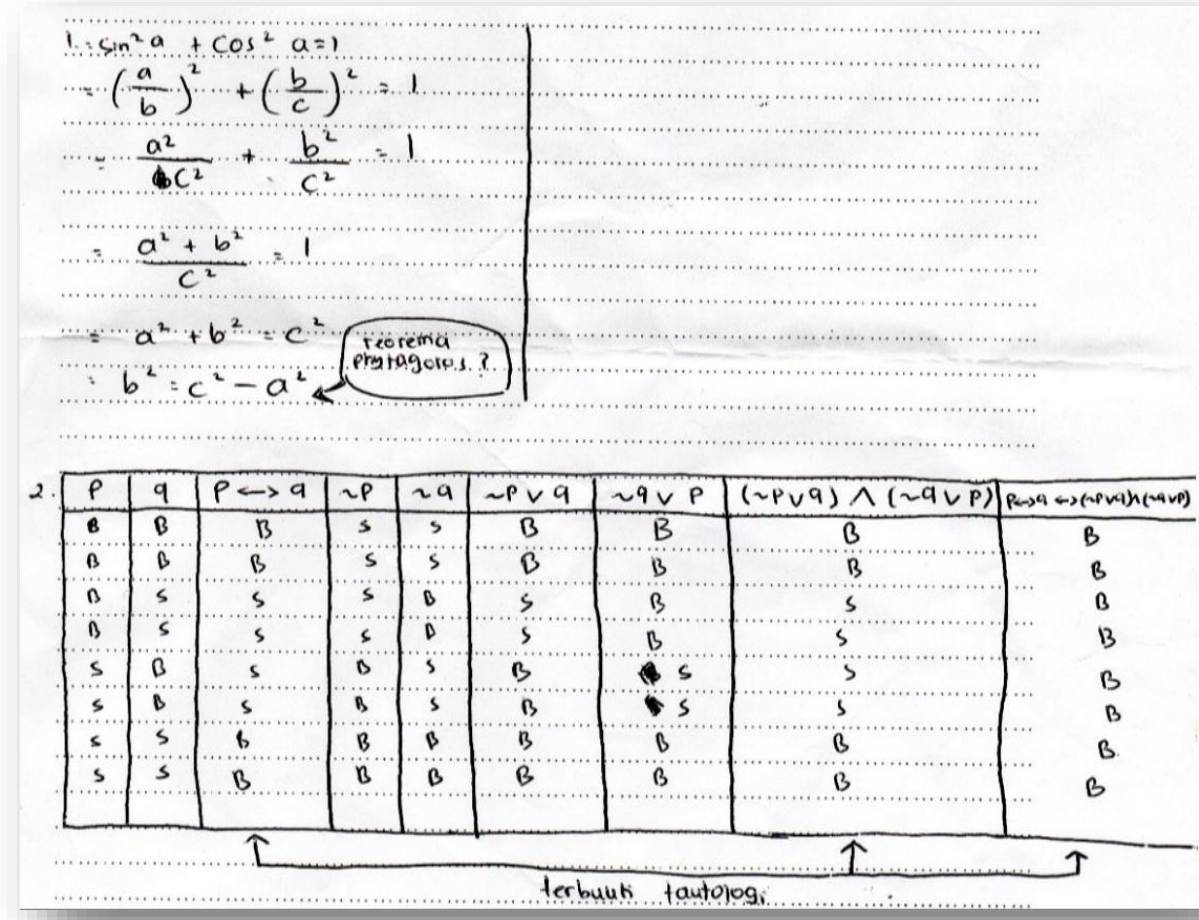

Gambar 2.1 . Hasil Jawaban Siswa dengan Kemampuan Berpikir Formal Sangat Baik

Hasil jawaban siswa dengan kemampuan sangat baik pada soal nomor 1 menunjukkan bahwa siswa mampu memberikan alasan disetiap langkah yang dilakukan hingga memperoleh kesimpulan dengan benar. siswa mengawali pembuktian dengan cara menjabarkan pernyataan yang ingin dibuktikan yaitu $\sin ^{2} \alpha+\cos ^{2} \alpha=1$. Selanjutnya dengan pengetahuan yang dimiliki siswa bahwa $\sin \alpha=\frac{a}{c}$ dan $\cos \alpha=\frac{b}{c}$ dengan $a$ adalah sisi depan, $b$ adalah sisi samping dan $c$ adalah sisi miring, siswa menjabarkan pengetahuan tersebut dengan kuadrat masing-masing bagian yakni $\sin ^{2} \alpha=\frac{a^{2}}{c^{2}}$ dan $\cos \alpha=\frac{b^{2}}{c^{2}}$. Dengan pemahaman konsep pecahan siswa menulis $\frac{a^{2}}{c^{2}}+\frac{b^{2}}{c^{2}}=1$ menjadi $\frac{a^{2}+b^{2}}{c^{2}}=1$. Dari bentuk ini siswa kemudian mengalikan kedua ruas dengan $c^{2}$ (atau dengan bahasa umum bagi siswa adalah kali silang) sehingga 
menjadi $a^{2}+b^{2}=c^{2}$. Bentuk inilah yang kemudian siswa ingat sebagai bentuk umum dari rumus phytagoras. Dengan pengetahuan siswa akan rumus phytagoras inilah yang menunjukkan bahwa pembuktian pernyataan $\sin ^{2} \alpha+\cos ^{2} \alpha=1$ adalah terbukti benar.

Hasil jawaban siswa dengan kemampuan sangat baik pada soal nomor 2 menunjukkan bahwa siswa mampu memberikan alasan disetiap langkah yang dilakukan hingga memperoleh kesimpulan dengan benar. siswa melakukan pembuktian terhadap suatu pernyataan $(p \leftrightarrow q) \leftrightarrow$ $[(\sim p \vee q) \wedge(\sim q \vee p)]$ adalah tautology dengan membuat tabel kebenaran. Kemungkinan nilai kebenaran untuk pernyataan $p$ dan $q$ yang digunakan siswa pada tabel kebenaran ditulis dua kali padahal satu kali saja sudah cukup seperti pada kemungkinan nilai kebenaran kolom $p$ adalah BBBBSSSS, padahal cukup dengan menulis BBSS saja sudah cukup. Hal ini tidak membuat jawaban siswa dikatakan salah. Mengawali pembuktian dengan menggunakan tabel kebenaran, siswa membuat kolom untuk pernyataanpernyataan partisi dari pernyataan yang ingin dibuktikan. Partisi yang dimaksud adalah kolom $p, q, \sim p, \sim q, p \leftrightarrow$ $q, \sim p \vee q, \sim q \vee p, \operatorname{dan}(\sim p \vee q) \wedge(\sim q \vee p)$. Untuk kolom $p$ siswa menulis nilai kebenaran BBSS, kemudian untuk kolom $q$ siswa menulis BSBS. Hal ini menunjukkan pemahaman konsep siswa dalam membuat kemungkinan yang muncul jika terdapat dua pernyataan. Selanjutnya siswa menulis kolom $(p \leftrightarrow q)$ dengan BSSB, hal ini menunjukkan siswa memiliki pengetahuan tentang nilai kebenaran biimplikasi (bernilai benar jika kedua pernyataan benar atau salah dan bernilai salah jika sebaliknya). Pada kolom $\sim p$ siswa menulis SSBB dan kolom $\sim q$ siswa menulis SBSB, hal ini menunjukkan siswa memiliki pemahaman tentang negasi (bernilai salah jika pernyataan benar dan bernilai benar jika pernyataan salah). Pada kolom $(\sim p \vee q)$ siswa menulis BSBB dan kolom $(\sim q \vee p)$ siswa menulis BBSB, hal ini menunjukkan siswa memiliki pemahaman tentang disjungsi (bernilai salah jika kedua pernyataan bernilai salah dan bernilai benar jika sebaliknya). Pada kolom $[(\sim p \vee q) \wedge(\sim q \vee p)]$ siswa menulis BSSB, hal ini menunjukkan siswa memiliki pemahaman tentang konjungsi (bernilai benar jika kedua 
pernyataan bernilai benar dan bernilai salah jika sebaliknya). Kolom terakhir yakni $(p \leftrightarrow q) \leftrightarrow[(\sim p \vee q) \wedge(\sim q \vee p)]$ siswa menulis BBBB, hal ini menunjukkan siswa memiliki pemahaman biimplikasi dengan mengaitkan kolom $(p \leftrightarrow q)$ sebagai pernyataan pertama dan kolom $[(\sim p \vee q) \wedge(\sim q \vee p)]$ sebagai pernyataan kedua. Pada kolom terakhir ini siswa menunjukkan bahwa pernyataan $(p \leftrightarrow q) \leftrightarrow[(\sim p \vee q) \wedge(\sim q \vee p)]$ adalah tautology yang merupakan pernyataan yang memiliki nilai kebenaran benar semua.

Dari hasil penyelesaian siswa pada dua soal tersebut menunjukkan siswa memiliki kemampuan berpikir formal sangat baik karena mampu memberikan alasan dari setiap pernyataan sehingga memperoleh kesimpulan dari apa yang ingin dibuktikan.

2. Siswa dengan Kemampuan Berpikir Formal Baik 


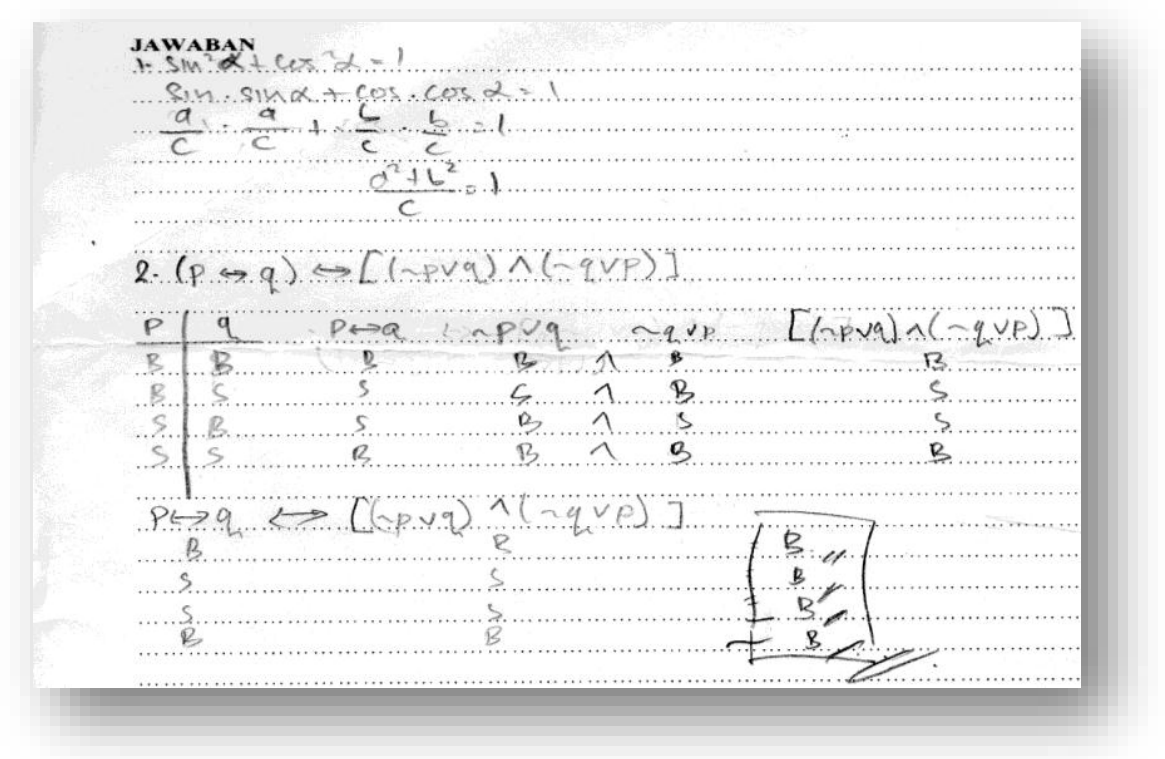

Gambar 2.2 Hasil Jawaban Siswa dengan Kemampuan Berpikir Formal Baik

Hasil jawaban siswa dengan kemampuan baik pada soal nomor 1 menunjukkan bahwa siswa mampu memberikan alasan disetiap langkah yang dilakukan hingga memperoleh kesimpulan kurang tepat atau terdapat kesalahan. siswa mengawali pembuktian dengan cara menjabarkan pernyataan yang ingin dibuktikan yaitu $\sin ^{2} \alpha+\cos ^{2} \alpha=1$. Selanjutnya dengan pengetahuan yang dimiliki siswa bahwa $\sin \alpha=\frac{a}{c}$ dan $\cos \alpha=\frac{b}{c}$ dengan $a$ adalah sisi depan, $b$ adalah sisi samping dan $c$ adalah sisi miring, siswa menjabarkan pengetahuan tersebut dengan kuadrat masing-masing bagian yakni $\sin ^{2} \alpha=\sin \alpha \cdot \sin \alpha=\frac{a}{c} \cdot \frac{a}{c}$ dan $\cos ^{2} \alpha=\cos \alpha \cdot \cos \alpha=\frac{b}{c} \cdot \frac{b}{c}$. selanjutnya siswa menulis $\frac{a^{2}+b^{2}}{c}=1$. Bentuk ini merupakan bentuk yang kurang tepat karena siswa seharusnya menulis $\frac{a^{2}+b^{2}}{c^{2}}=1$. Langkah ini juga merupakan langkah terakhir yang ditulis siswa sehingga siswa tidak dapat memberikan kesimpulan untuk membuktikan pernyataan pada soal nomor 1 tersebut.

Hasil jawaban siswa dengan kemampuan baik pada soal nomor 2 menunjukkan bahwa siswa mampu memberikan alasan disetiap langkah yang dilakukan hingga memperoleh kesimpulan dengan benar. siswa 
melakukan pembuktian terhadap suatu pernyataan $(p \leftrightarrow q) \leftrightarrow$ $[(\sim p \vee q) \wedge(\sim q \vee p)]$ adalah tautology dengan membuat tabel kebenaran.. Mengawali pembuktian dengan menggunakan tabel kebenaran, siswa membuat kolom untuk pernyataan-pernyataan partisi dari pernyataan yang ingin dibuktikan. Partisi yang dimaksud adalah kolom $p, q, \sim p, \sim q, p \leftrightarrow$ $q, \sim p \vee q, \sim q \vee p$, dan $(\sim p \vee q) \wedge(\sim q \vee p)$. Untuk kolom $p$ siswa menulis nilai kebenaran BBSS, kemudian untuk kolom $q$ siswa menulis BSBS. Hal ini menunjukkan pemahaman konsep siswa dalam membuat kemungkinan yang muncul jika terdapat dua pernyataan. Selanjutnya siswa menulis kolom $(p \leftrightarrow q)$ dengan BSSB, hal ini menunjukkan siswa memiliki pengetahuan tentang nilai kebenaran biimplikasi (bernilai benar jika kedua pernyataan benar atau salah dan bernilai salah jika sebaliknya). Pada kolom $\sim p$ siswa menulis SSBB dan kolom $\sim q$ siswa menulis SBSB, hal ini menunjukkan siswa memiliki pemahaman tentang negasi (bernilai salah jika pernyataan benar dan bernilai benar jika pernyataan salah). Pada kolom $(\sim p \vee q)$ siswa menulis BSBB dan kolom $(\sim q \vee p)$ siswa menulis BBSB, hal ini menunjukkan siswa memiliki pemahaman tentang disjungsi (bernilai salah jika kedua pernyataan bernilai salah dan bernilai benar jika sebaliknya). Pada kolom $[(\sim p \vee q) \wedge(\sim q \vee p)]$ siswa menulis BSSB, hal ini menunjukkan siswa memiliki pemahaman tentang konjungsi (bernilai benar jika kedua pernyataan bernilai benar dan bernilai salah jika sebaliknya). Kolom terakhir yakni $(p \leftrightarrow q) \leftrightarrow[(\sim p \vee q) \wedge(\sim q \vee p)]$ siswa menulis BBBB, hal ini menunjukkan siswa memiliki pemahaman biimplikasi dengan mengaitkan kolom $(p \leftrightarrow q)$ sebagai pernyataan pertama dan kolom $[(\sim p \vee q) \wedge(\sim q \vee p)]$ sebagai pernyataan kedua. Pada kolom terakhir ini siswa menunjukkan bahwa pernyataan $(p \leftrightarrow q) \leftrightarrow[(\sim p \vee q) \wedge(\sim q \vee p)]$ adalah tautology yang merupakan pernyataan yang memiliki nilai kebenaran benar semua.

Dari hasil penyelesaian siswa pada dua soal tersebut menunjukkan siswa memiliki kemampuan berpikir formal baik karena mampu memberikan alasan dari setiap pernyataan sehingga memperoleh 
kesimpulan kurang tepat atau terdapat kesalahan pada soal no 1 dan benar pada soal no 2 dari apa yang ingin dibuktikan.

3. Siswa dengan Kemampuan Berpikir Formal Cukup Baik

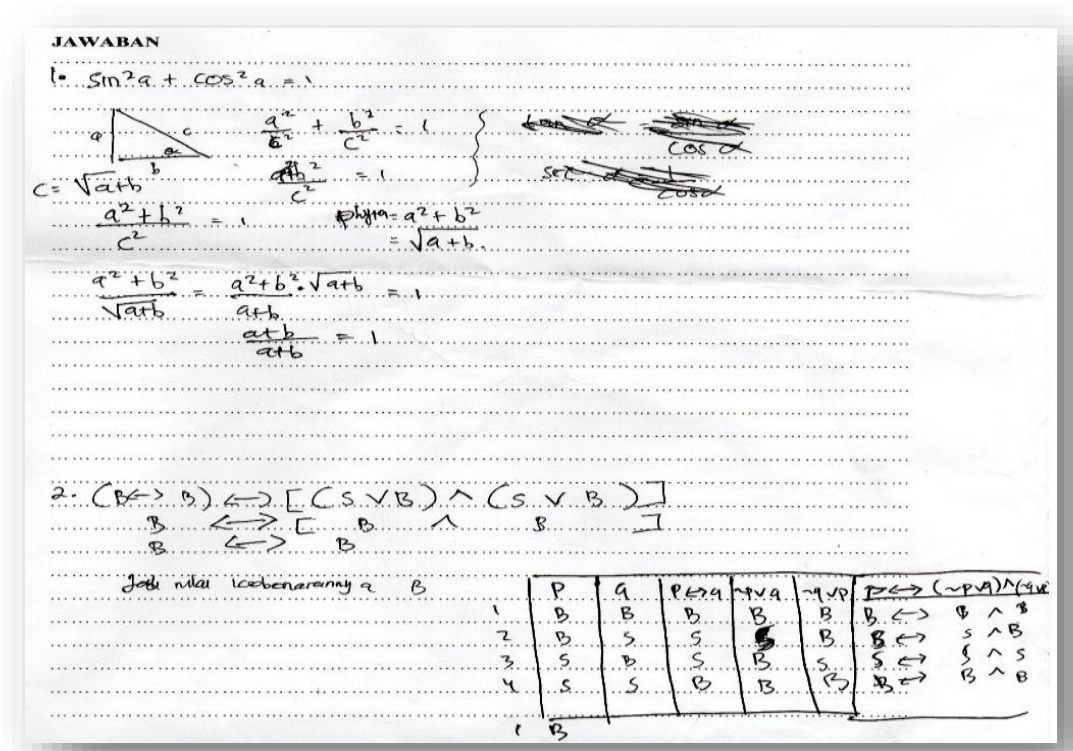

Gambar 2.3. Hasil jawaban Siswa dengan Kemampuan Berpikir Formal Cukup Baik

Hasil jawaban siswa dengan kemampuan cukup baik pada soal nomor 1 menunjukkan bahwa siswa mampu memberikan alasan disetiap langkah yang dilakukan hingga memperoleh kesimpulan kurang tepat atau terdapat kesalahan. siswa mengawali pembuktian dengan cara menjabarkan pernyataan yang ingin dibuktikan yaitu $\sin ^{2} \alpha+\cos ^{2} \alpha=1$. Selanjutnya dengan pengetahuan yang dimiliki siswa bahwa $\sin \alpha=\frac{a}{c}$ dan $\cos \alpha=\frac{b}{c}$ dengan $a$ adalah sisi depan, $b$ adalah sisi samping dan $c$ adalah sisi miring, siswa menjabarkan pengetahuan tersebut dengan kuadrat masing-masing bagian yakni $\sin ^{2} \alpha=\frac{a^{2}}{c^{2}}$ dan $\cos \alpha=\frac{b^{2}}{c^{2}}$. Dengan pemahaman konsep pecahan siswa menulis $\frac{a^{2}}{c^{2}}+\frac{b^{2}}{c^{2}}=1$ menjadi $\frac{a^{2}+b^{2}}{c^{2}}=1$. Dari bentuk ini siswa kemudian mengganti $c^{2}$ dengan $\sqrt{a}+b$, langkah ini siswa bingung mengoperasikan selanjutnya sehingga tidak menemukan jawaban yang benar.

Hasil jawaban siswa dengan kemampuan cukup baik pada soal nomor 2 menunjukkan bahwa siswa mampu memberikan alasan disetiap langkah 
yang dilakukan hingga memperoleh kesimpulan kurang tepat atau terdapat kesalahan. Siswa melakukan pembuktian terhadap suatu pernyataan $(p \leftrightarrow q) \leftrightarrow[(\sim p \vee q) \wedge(\sim q \vee p)]$ adalah tautology dengan membuat tabel kebenaran. Siswa mengawali pembuktian dengan menggunakan tabel kebenaran, siswa membuat kolom untuk pernyataan-pernyataan partisi dari pernyataan yang ingin dibuktikan. Partisi yang dimaksud adalah kolom $p, q$, $(p \leftrightarrow q),(\sim p \vee q),(\sim q \vee p), p \leftrightarrow[(\sim p \vee q) \wedge(\sim q \vee p)]$. Untuk kolom $p$ siswa menulis nilai kebenaran BBSS, kemudian untuk kolom $q$ siswa menulis BSBS. Hal ini menunjukkan pemahaman konsep siswa dalam membuat kemungkinan yang muncul jika terdapat dua pernyataan. Selanjutnya siswa menulis kolom ( $p \leftrightarrow q$ ) dengan BSSB, hal ini menunjukkan siswa memiliki pengetahuan tentang nilai kebenaran biimplikasi (bernilai benar jika kedua pernyataan benar atau salah dan bernilai salah jika sebaliknya). Pada kolom $(\sim p \vee q)$ siswa menulis BSBB dan kolom $(\sim q \vee p)$ siswa menulis BBSB, hal ini menunjukkan siswa memiliki pemahaman tentang disjungsi (bernilai salah jika kedua pernyataan bernilai salah dan bernilai benar jika sebaliknya). Pada kolom $p \leftrightarrow[(\sim p \vee q) \wedge(\sim q \vee p)]$ siswa sudah salah menuliskan soal yang dibuktikan. hal ini menunjukkan siswa kurang memiliki ketelitian, Pada kolom terakhir ini siswa menunjukkan suatu pernyataan kurang tepat atau terdapat kesalahan sehingga tidak dapat membuktikan kebenaran.

Dari hasil penyelesaian siswa pada dua soal tersebut menunjukkan siswa memiliki kemampuan berpikir formal cukup baik karena mampu memberikan alasan dari setiap pernyataan namun terdapat kesalahan pada kedua soal tersebut.

\section{B. Kemampuan Berpikir Formal Siswa dengan Gaya Kognitif Field Dependent}

Dari hasil penelitian diperoleh bahwa dari 66 siswa yang diberikan tes GEFT terdapat 36 siswa dengan gaya kognitif field dependent. Dari 36 siswa dengan gaya kognitif field dependent tersebut terdiri dari 6 siswa dengan kemampuan berpikir formal cukup baik artinya 16\% siswa yang kemampuan 
berpikir formal cukup baik dan 30 siswa dengan kemampuan berpikir formal kurang. Hasil ini menunjukkan bahwa 84\% siswa gaya kognitif field dependent terdiri dari siswa dengan kemampuan berpikir formal kurang.

Berikut data diatas disajikan dalam bentul tabel dibawah ini.

Tabel 3.2 Kemampuan Berpikir Formal Siswa Berdasarkan Gaya Kognitif FD

\begin{tabular}{|c|c|c|c|c|c|}
\hline No & Nama & Skor & Gaya Kognitif & Skor & Ket \\
\hline 1 & Yoyanda Eka Mawadda & 4 & Field Dependent & 25 & Kurang \\
\hline 2 & Indah Amalia & 6 & Field Dependent & 25 & Kurang \\
\hline 3 & Ruth Anastasya Putri D. & 7 & Field Dependent & 25 & Kurang \\
\hline 4 & Astried Salma Fahira & 7 & Field Dependent & 25 & Kurang \\
\hline 5 & Nengah Bela Arianti & 9 & Field Dependent & 25 & Kurang \\
\hline 6 & Reflyne Safira Prasetio & 9 & Field Dependent & 50 & Cukup Baik \\
\hline 7 & Putri Agustina & 8 & Field Dependent & 0 & Kurang \\
\hline 8 & Siska Mirtha Diana Sari & 7 & Field Dependent & 0 & Kurang \\
\hline 9 & Anggun Putri Setyadi & 9 & Field Dependent & 50 & Cukup Baik \\
\hline 10 & Amelia Haura Salsabila Ansori & 2 & Field Dependent & 25 & Kurang \\
\hline 11 & Prayidhe Ade Gayana & 9 & Field Dependent & 50 & Cukup Baik \\
\hline 12 & Dendy Arya Raditya P.E & 8 & Field Dependent & 25 & Kurang \\
\hline 13 & Rifqi Qwhoyyi & 8 & Field Dependent & 50 & Cukup Baik \\
\hline 14 & Ferdi Rizki Ramdhani & 7 & Field Dependent & 25 & Kurang \\
\hline 15 & Muhammad Icha Setiawan & 9 & Field Dependent & 0 & Kurang \\
\hline 16 & Riza Anissa Triama S & 7 & Field Dependent & 50 & Cukup baik \\
\hline 17 & Dea Sakila Putri & 9 & Field Dependent & 25 & Kurang \\
\hline 18 & Ni Luh Putu Apriliani & 8 & Field Dependent & 25 & Kurang \\
\hline 19 & Vina Vironika Santi & 8 & Field Dependent & 25 & Kurang \\
\hline 20 & Dwi Tri Okta Meliana Lestari & 6 & Field Dependent & 0 & Kurang \\
\hline 21 & Jullia Mawarni & 9 & Field Dependent & 25 & Kurang \\
\hline 22 & Silka Silvia & 6 & Field Dependent & 25 & Kurang \\
\hline 23 & Dina Febriana & 2 & Field Dependent & 25 & Kurang \\
\hline 24 & Nadia & 0 & Field Dependent & 0 & Kurang \\
\hline 25 & Ni Putu Ayu Yogi A & 6 & Field Dependent & 0 & Kurang \\
\hline 26 & Bila Marsidita & 9 & Field Dependent & 50 & Cukup baik \\
\hline 27 & Wulandara & 5 & Field Dependent & 25 & Kurang \\
\hline 28 & Tania Oktavianingsih & 8 & Field Dependent & 25 & Kurang \\
\hline 29 & Selvin Ayu Alivira & 0 & Field Dependent & 0 & Kurang \\
\hline 30 & Akhmad Faiz Firjatullah & 9 & Field Dependent & 25 & Kurang \\
\hline 31 & I Made Dwi Andika Saputra & 8 & Field Dependent & 25 & Kurang \\
\hline 32 & Muhammad Rafli Rafsanjani & 8 & Field Dependent & 0 & Kurang \\
\hline 33 & Made Picky Angco & 6 & Field Dependent & 25 & Kurang \\
\hline
\end{tabular}




\begin{tabular}{|l|l|r|l|r|l|}
34 & Muhammad Aria. M & 4 & Field Dependent & 25 & Kurang \\
\hline 35 & Sohibul Kahfi & 6 & Field Dependent & 25 & Kurang \\
\hline 36 & Moh. Taupiq & 3 & Field Dependent & 0 & Kurang \\
\hline
\end{tabular}

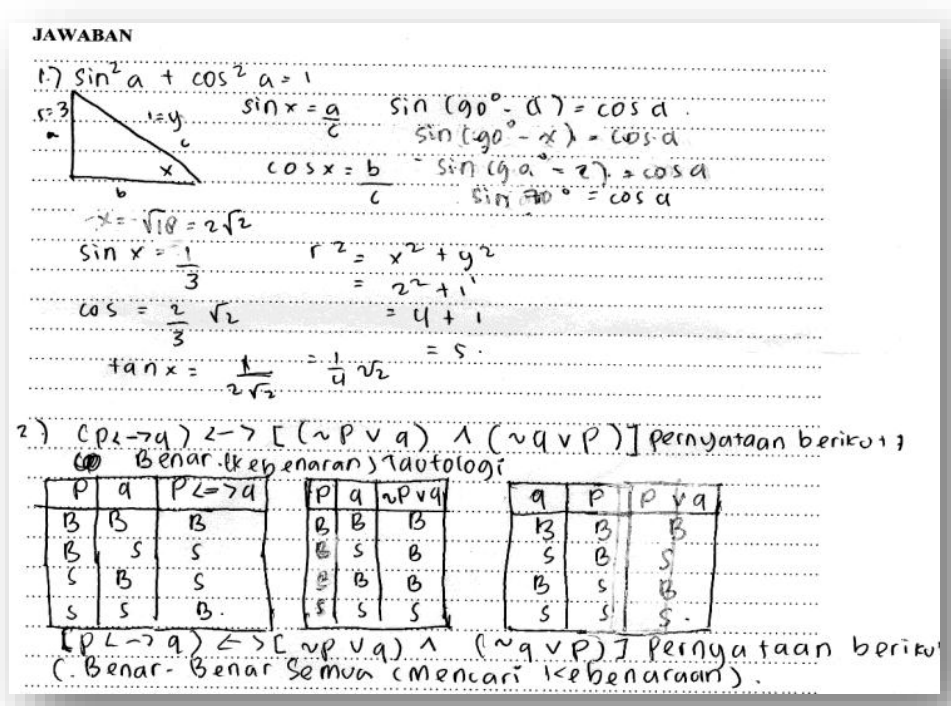

Gambar 2.4. Hasil Jawaban Siswa dengan Kemampuan Berpikir Formal

\section{Kurang Baik}

Siswa gaya kognitif field dependent dengan kemampuan berpikir kurang tidak dapat memberikan alasan disetiap langkah yang dilakukan. Dalam jawaban siswa tersebut nampak bahwa siswa kebingungan dalam menyelesaikan soal tersebut dan tidak tahu harus memulai dari mana. Siswa mampu menggambar segi tiga siku-siku sebagai landasan berpikir dengan menulis $\sin ^{2} \alpha+\cos ^{2} \alpha=1$. Akan tetapi siswa tidak dapat merepresentasikan pernyataan tersebut sehingga memperoleh kesimpulan yang tepat dari permintaan soal untuk membuktikan pernyataan tersebut. Dari gambar segitiga siku-siku yang ditulis siswa terlihat bahwa siswa ingin menunjukkan dengan bilangan dengan sisi miringnya adalah 1. Akan tetapi siswa kesulitan dalam menemukan nilai sisi samping (datar) dan nilai sisi depan (tegak). Siswa seakan ingin membuktikan pernyataan $\sin ^{2} \alpha+$ $\cos ^{2} \alpha=1$ dengan mengambil nilai $\sin \alpha=\frac{1}{3}$ dan $\cos \alpha=\frac{2}{3} \sqrt{2}$. Nilai tersebut langsung disubstitusikan ke pernyataan $\sin ^{2} \alpha+\cos ^{2} \alpha=1$ dan menghasilkan $\left(\frac{1}{3}\right)^{2}+\left(\frac{2}{3} \sqrt{2}\right)^{2}=\frac{1}{9}+\frac{8}{9}=\frac{9}{9}=1$. Hasil yang diperoleh dari proses ini memang terbukti benar akan tetapi seperti ini bukanlah proses 
pembuktian formal dalam matematika. Pembuktian dengan mengambil sebarang bilangan untuk membuktikan konjektur bukanlah cara yang tepat karena tidak dapat diambil kesimpulan untuk semua bilangan. Dengan demikian siswa dengan kemampuan kurang hanya mampu menunjukkan kebenaran dari pernyataan $\sin ^{2} \alpha+\cos ^{2} \alpha=1$ dengan mengambil sebarang bilangan akan tetapi tidak dapat membuktikan secara formal pernyataan tersebut dengan memberikan alasan-alasan yang logis.

Hasil jawaban siswa dengan kemampuan kurang pada soal no 2 menunjukkan siswa tidak dapat memberikan alasan untuk mendapatkan kesimpulan yang benar. siswa mengawali penyelesaian dengan membuat tabel kebenaran untuk $p \leftrightarrow q$. Pada langkah ini siswa memiliki pengetahuan konsep tentang biimplikasi dengan nilai kebenaran BSSB untuk pernyataan $p$ dan $q$. pada langkah kedua siswa membuat tabel untuk $\sim p \vee q$ akan tetapi pada langkah ini siswa belum memahami secara utuh konsep disjungsi dengan pernyataan $\sim p$ dan $q$ dan siswa malah menulis nilai kebenaran untuk $p \vee q$ dengan nilai kebenaran BBBS. Pada langkah tersebut seharusnya siswa menambahkan satu kolom untuk $\sim$ p dengan nilai kebenaran SSBB kemudian menyesuaikan nilai kebenaran konjungsi dengan pernyataan q. pada langkah kedua ini siswa dengan kemampuan kurang sudah melakukan kesalahan yang akan berdampak pada terjadinya kesimpulan yang tidak tepat. Pada langkah ketiga siswa membuat tabel kebenaran untuk pernyataan $p \vee q$. Pernyataan ini tidak berhubungan dengan pernyataan yang akan dibuktikan sehingga pada langkah ini siswa sudah salah dalam menentukan langkah penyelesaian. Dengan langkah kedua dan ketiga yang salah membuat siswa dengan kemampuan kurang tidak dapat menunjukkan bahwa pernyataan $(p \leftrightarrow q) \leftrightarrow[(\sim p \vee q) \wedge(\sim q \vee p)]$ adalah tautology yang merupakan pernyataan yang memiliki nilai kebenaran benar semua. Dengan demikian dapat dikatakan bahwa siswa dengan kemampuan kurang tidak dapat memberikan alasan untuk mendapatkan kesimpulan yang tepat dari soal no 2 ini.

Dari hasil pembahasan di atas dapat disimpulkan bahwa kemampuan berpikir formal siswa gaya kognitif field dependent cenderung kurang baik. 
Hasil ini sesuai dengan pendapat Town (2010) yang menyatakan bahwa siswa dengan gaya kognitif field dependent cenderung infulsif dalam berpikir, kurang kreatif dan berkembang berdasarkan imajinasi.

Kecenderungan infulsif dalam berpikir nampak dari jawaban siswa yang tidak memiliki alasan yang logis dalam setiap langkah yang dilakukan dalam menyelesaikan soal. Kurangnya kemampuan berpikir kreatif membuat siswa tidak dapat memberikan jawaban yang berbeda dan bahkan kebingungan dalam menyelesaikan soal. Hal ini dipertegas dengan kurangnya pemahaman konsep matematika siswa yang menyebabkan langkah penyelesaian yang tidak berdasar.

\section{PENUTUP}

Berdasarkan analisis data dan pembahasan, maka diperoleh simpulan dalam penelitian ini sebagai berikut; (1)Kemampuan berpikir fomal siswa gaya kognitif field independent terdiri dari kemampuan berpikir formal sangat baik, baik dan cukup baik. Kemampuan berpikir formal sangat baik ditunjukkan dengan kemampuan memberikan alasan disetiap langkah yang dilakukan hingga memperoleh kesimpulan yang benar pada dua soal yang diberikan. Kemampuan berpikir formal baik ditunjukkan dengan kemampuan memberikan alasan disetiap langkah yang dilakukan hingga memperoleh kesimpulan kurang tepat atau terdapat kesalahan pada salah satu soal yang diberikan. Kemampuan berpikir formal cukup baik ditunjukkan dengan kemampuan memberikan alasan disetiap langkah yang dilakukan hingga memperoleh kesimpulan kurang tepat atau terdapat kesalahan pada dua soal yang diberikan, (2) Kemampuan berpikir formal siswa gaya kognitif field dependent cenderung kurang baik. Hal ini ditunjukkan dengan ketidakmampuan siswa dalam memberikan alasan disetiap langkah yang diberikan.

\section{DAFTAR PUSTAKA}

Afifuddi, Prof. Dr. H, \& Saebeni, Beni Ahmad, Drs., M.Si., 2012. Metodologi Penelitian Kualitatif. Bandung:Pustaka Setia.

Aiken, Lewis R. 1997. Psychological testing and Assessment, Boston: Allyn. 
Arikunto, S. 2006. Prosedur Penelitian: Suatu Pendekatan Priaktik. Jakarta: Rineka Cipta.

Ferri, Rita Borromeo. 2012. Mathematical Thinking Styles and Their Influence on Teaching and Learning Mathematics. Internasional Congress on Mathematical Education.

NCTM. 1998. Problem Solving in School Mathematics. Reston:NCTM

Peraturan Menteri Pendidikan Nasional Nomor 2 Tahun 2006

Piaget, J. 1972. Intelectual Evolution from Adolescence to Adulthood. Human Development.

Siswono, Tatag Yuli. 2008. Model Pembelajaran Matematika Berbasis Pengajuan dan Pemecahan Masalah untuk Meningkatkan Kemampuan Berfikir Kreatif. Surabaya: Unesa University Press.

Suherman, E. dkk (2003). Strategi pembelajaran matematika kontemporer. Bandung: UPI.

Tall, D.O. 2008e. The Transition to Formal Thinking in Mathematics. Mathematics Education Research Journal, Vol. 20 No. 2 Hal: 5-24.

Witkin,H.A.dkk, 1979. Field Dependent and Field Independent Cognitive Styles and Their Education Implication, New York : American Education Research Journal,. 